\title{
ANALISIS FAKTOR YANG BERHUBUNGAN DENGAN KEPATUHAN DIET PENDERITA DIABETES MELITUS
}

\author{
Rohani, Ardenny* \\ *Jurusan Keperawatan Politeknik Kesehatan Kemenkes Riau
}

\begin{abstract}
ABSTRAK
Kepatuhan pengobatan penderitan Diabetes Melitus merupakan suatu perilaku pasien dalam menjalani pengobatan, mengikuti diet, atau mengikuti perubahan gaya hidup lainnya sesuai dengan anjuran medis dan kesehatan. Tujuan penelitian ini adalah untuk mengetahui mengetahui analisis faktor yang berhubungan dengan kepatuhan diet Penderita Diabetes Melitus di wilayah kerja Puskesmas Harapan Raya. Rancangan penelitian ini menggunakan pendekatan analisis uji statistik uji regeresi logistik berganda dengan sampel yang ditetapkan adalah seluruh penderita Diabetes Melitus berjumlah 100 orang. Instrumen penelitian menggunakan kuesioner dan lembar observasi dengan metode pengumpulan data melalui data sekunder dan data primer melalui proses wawancara dan oberservasi lapangan. Hasil penelitian ini menunjukkan bahwa Faktor pekerjaan memberikan peluang 7,255 kali mempengaruhi kepatuhan diet diabetes melitus (C.I. 2,302 - 22,869). Faktor umur, pengetahuan, dan dukungan keluarga memberikan peluang 0,124-0,216 kalimempengaruhi kepatuhan diet diabetes.

Sedangkan variabel yang menjadi counfounding adalah variabel dukungan tenaga kesehatan. Disarankan pada pihak Puskesmas Harapan Raya untuk memanfaatkan data hasil penelitian ini untuk peningkatakan kepatuhan pasien Diabetes Melitus melalui peran petugas kesehatannya.
\end{abstract}

Keywords: Diabetes Melitus, Kepatuhan 


\section{PENDAHULUAN}

Diabetes Melitus (DM) merupakan kelompok penyakit metabolik dengan karakteristik hiperglikemia yang terjadi karena kelainan sekresi insulin, kerja insulin, atau keduanya (American Diabetes Association, 2006). Secara klinis terdapat dua tipe DM, yaitu DM tipe 1 yang disebabkan kurangnya insulin secara absolut akibat proses autoimun dan DM tipe 2 yang merupakan kasus terbanyak (90-95\% dari seluruh kasus DM) yang umumnya mempunyai latar belakang kelainan diawali dengan resistensi insulin (Soegondo, 2007). DM tipe 2 berlangsung lambat dan progresif, sehingga berjalan tanpa terdeteksi karena gejala yang dialami pasien sering bersifat ringan seperti kelelahan, irritabilitas, poliuria, polidipsi, dan luka yang lama sembuh (Smeltzer dan Bare, 2008).

Berdasarkan Penelitian yang dilakukan oleh Abdurrachim (2008) di Banjarmasin didapatkan hasil sebanyak $71,1 \%$ pasien Diabetes Mellitus tidak patuh terhadap program diet yang dianjurkan, variabel yang berhubungan dengan ketidakpatuhan adalah pengetahuan ( $\mathrm{p}$ value 0,003 ), sikap $(0,10)$, dukungan keluarga $(0,25)$. Begitu juga penelitian yang dilakukan oleh David (2013) tentang analisis faktor yang berhubungan dengan kepatuhan program diet pada penderita DM di Kelurahan Kemiri Muka Depok didapatkan bahwa $75 \%$ pasien Diabetes Mellitus tidak patuh terhadap aktivitas fisik/olahraga yang dianjurkan. Variabel yang dominan mempengaruhi ketidakpatuhan adalah pengetahuan $(0,001)$ dan peran petugas $(0,007)$ setelah dikontrol dengan pendidikan, sikap, dan pekerjaan.

Menurut Green (Notoadmojdo, 2010) ada beberapa faktor yang dapat mempengaruhi perubahan perilaku klien untuk menjadi taat atau tidak taat terhadap program pengobatan, yang diantaranya dipengaruhi oleh faktor predisposisi (pengetahuan), faktor pendukung (pendidikan) serta faktor pendorong (keluarga dan petugas).

Hasil survey pendahuluan yang dilakukan oleh peneliti saat pasien berkunjung di Puskesmas Harapan Raya belum ditemukan faktor penyebab ketidakpatuhan pasien dalam menjalankan program diet. Umumya pasien mengatakan masih memerlukan informasi, dukungan keluarga dan petugas dalam menjalankan program diet. Berdasarkan latar belakang di atas peneliti tertarik untuk meneliti tentagn Analisis faktor yang Berhubungan dengan Kepatuhan Diet Penderita DM di wilayah kerja Puskesmas Harapan Raya Tahun 2018.

\section{METODE PENELITIAN}

Metode penelitian ini menggunakan penelitian analitik dengan rancangan Crossectionaldengan uji statistik regresi logistik berganda untuk menentukan faktr dominan yang mempengaruhi kepatuhan diet Diabetes Melitus.

\section{CARA PENGUMPULAN DATA}

Pengumpulan data penelitian ini dengan menggunakan lembar checklist. Peneliti mengumpulkan responden dengan bekerjasama dengan peemgang program Pengendalian dan Penatalaksanaan penyakit Kronis (Prolanis) di dalam satu ruangan pertemuan Puskesmas Harapan Raya. Pengisian kuesioner didampingi oleh peneliti untuk menghindari bias dalam menjawab oleh karena faktor usia responden.

\section{ANALISIS DATA}

Penelitian ini menggunakan analisis uji stataistik Multivariat yaitu regeresi logistik berganda dengan nilai kemaknaan $\alpha \leq 0,05$.

\section{HASIL DAN PEMBAHASAN}

Karakteristik responden umumnya responden berusia tua (58-79 tahun) yaitu sebanyak 75 orang (75\%), berjenis kelamin perempuan sebanyak 61 orang (61\%), berpendidikan rendah sebanyak 88 orang (88\%), tidak bekerja sebanyak 69 orang $(69 \%)$, responden patuh dalam program diet sebanyak 64 orang $(64 \%)$, memiliki pengetahuan kurang baik sebanyak 55 orang (55\%), mendapat dukungan dari keluarga sebanyak 55 orang (55\%), dan mendapat dukungan dari tenga kesehatan sebanyak 50 orang (50\%). 
Tabel 1.1 Hubungan Umur dengan Kepatuhan Diet

\begin{tabular}{|c|c|c|c|c|c|c|c|}
\hline \multirow{3}{*}{$\begin{array}{c}\text { Um } \\
\mathbf{u r}\end{array}$} & \multicolumn{4}{|c|}{ Kepatuahn Diet } & \multirow{2}{*}{\multicolumn{2}{|c|}{ Jumlah }} & \multirow{3}{*}{$\begin{array}{c}\mathbf{P} \\
\text { Val } \\
\text { ue }\end{array}$} \\
\hline & \multicolumn{2}{|c|}{$\begin{array}{c}\text { Kuran } \\
\text { g }\end{array}$} & \multicolumn{2}{|c|}{ Patuh } & & & \\
\hline & n & $\%$ & $\mathbf{n}$ & $\%$ & $\mathbf{N}$ & $\%$ & \\
\hline Mud & 1 & 44 & 1 & 56,0 & 25 & 10 & \\
\hline$a$ & 1 & 0 & 4 & 66,7 & 75 & 0 & 0,47 \\
\hline Tua & 2 & 33 , & 5 & & & 10 & 0 \\
\hline & 5 & 3 & 0 & & & 0 & \\
\hline Tota & 3 & 36 , & 6 & 64,0 & 10 & 10 & \\
\hline 1 & 6 & 0 & 4 & & 0 & 0 & \\
\hline
\end{tabular}

Tabel 1.1 menunjukkan bahwa umur tua sebagian besar patuh dalam program diet yaitu sebanyak 50 orang $(66,7 \%)$.Hasil uji statistik dengan uji chi square diperoleh p value $0,470>$ 0,05 tidak terdapat hubungan yang signifikan antara umur dengan kepatuhan diet. Penelitian ini sejalan dengan penelitian Liu (2004) mempelajari kemampuan orang dewasa yang lebih tua untuk mengingat dalam memantau glukosa mereka sebanyak empat kali dalam waktu yang sudah ditentukan. Dalam penelitiannya menyatakan bahwa tidak ada hubungan antara usia dengan kepatuhan dalam pengelolaan kepatuhan diet DM.

\section{Tabel 1.2 Hubungan Jenis Kelamin} dengan Kepatuhan Diet

\begin{tabular}{|c|c|c|c|c|c|c|c|}
\hline \multirow{3}{*}{ JK } & \multicolumn{4}{|c|}{ Kepatuahn Diet } & & & \multirow{3}{*}{$\begin{array}{c}\mathbf{P} \\
\text { Valu } \\
\mathbf{e}\end{array}$} \\
\hline & \multicolumn{2}{|c|}{ Kurang } & \multicolumn{2}{|c|}{ Patuh } & \multicolumn{2}{|c|}{ Jumlah } & \\
\hline & $n$ & $\%$ & $\mathbf{n}$ & $\%$ & $\mathbf{N}$ & $\%$ & \\
\hline Laki & 1 & 35,9 & 2 & 64,1 & 39 & 10 & \\
\hline \multirow[t]{3}{*}{ Wanita } & 4 & 36,1 & 5 & 63,9 & 61 & 0 & 1,00 \\
\hline & 2 & & 3 & & & 10 & \\
\hline & 2 & & 9 & & & 0 & \\
\hline \multirow[t]{2}{*}{ Total } & 3 & 36,0 & 6 & 64,0 & 10 & 10 & \\
\hline & 6 & & 4 & & 0 & 0 & \\
\hline
\end{tabular}

Tabel 1.2 menunjukan bahwa jenis kelamin laki-laki sebagian besar patuh dalam program diet yaitu sebanyak 25 orang $(64,1 \%)$. Hasil uji statistik dengan uji chi square diperoleh $\mathrm{p}$ value $1,000>0,05$ tidak terdapat hubungan yang signifikan antara jenis kelamin dengan kepatuhan diet. Penelitian Tania (2016) menunjukkan bahwa tidak ada hubungan yang bermakna antara jenis kelamin engan kepatuhan diet pada pasien DM. Ketidakbermaknaan antara jenis kelamin dengan kepatuhan diet dapat disebabkan karena jenis kelamin bukan merupakan faktor yan berhubungan langs ungdengan perilaku kepatuhan seperti yang diungkapkan dalam teori Health Belief Model atau model kepercayaan kesehatan.

Tabel 1.3 Hubungan Pendidikan dengan Kepatuhan Diet

\begin{tabular}{|c|c|c|c|c|c|c|c|}
\hline \multirow{3}{*}{$\begin{array}{l}\text { Pen } \\
\text { didi } \\
\text { kan }\end{array}$} & \multicolumn{4}{|c|}{ Kepatuahn Diet } & \multirow{2}{*}{\multicolumn{2}{|c|}{ Jumlah }} & \multirow{3}{*}{$\begin{array}{c}\mathbf{P} \\
\text { Val } \\
\text { ue }\end{array}$} \\
\hline & \multicolumn{2}{|c|}{$\begin{array}{c}\text { Kuran } \\
\text { g }\end{array}$} & \multicolumn{2}{|c|}{ Patuh } & & & \\
\hline & $\mathbf{n}$ & $\%$ & $\mathbf{n}$ & $\%$ & $\mathbf{N}$ & $\%$ & \\
\hline Rnd & 3 & 35 , & 5 & 64,8 & 88 & 10 & \\
\hline $\mathrm{h}$ & 1 & 2 & 7 & 58,3 & 12 & 0 & 0,90 \\
\hline $\begin{array}{l}\text { Ting } \\
\text { gi }\end{array}$ & 5 & $\begin{array}{c}41, \\
7\end{array}$ & 7 & & & $\begin{array}{l}10 \\
0\end{array}$ & 8 \\
\hline Tota & 3 & 36 , & 0 & 64,0 & 10 & 10 & \\
\hline 1 & 6 & 0 & 4 & & 0 & 0 & \\
\hline
\end{tabular}

Tabel 1.3 menunjukkan bahwa pendidikan rendah sebagian besar patuh dalam program diet yaitu sebanyak 57 orang $(64,8 \%)$.Hasil uji statistik dengan uji chi square diperoleh $\mathrm{p}$ value $0,908>0,05$ tidak terdapat hubungan yang signifikan antara pendidikan dengan kepatuhan diet. Menurut Heryati (2014) seseorang yang berpendidikan lebih tinggi akan mempunyai pengetahuan yang lebih luas dibandingkan dengan seseorang yang tingkat pendidikannya lebih rendah karena pendidikan merupakan dasar utama untuk keberhasilan dalam pengobatan. Beberapa penelitian di Indonesia juga menunjukkan hasil yang serupa dengan penelitian ini dimana tingkat pendidikan tidak memiliki pengaruh yang signifikan dengan kepatuhan diet pada penderita DM 
Tabel 1.4 Hubungan Pekerjaan dengan Kepatuhan Diet

\begin{tabular}{|c|c|c|c|c|c|c|c|}
\hline \multirow{3}{*}{$\begin{array}{c}\text { Pek } \\
\text { erja } \\
\text { an }\end{array}$} & \multicolumn{4}{|c|}{ Kepatuahn Diet } & \multirow{2}{*}{\multicolumn{2}{|c|}{ Jumlah }} & \multirow{3}{*}{$\begin{array}{c}\mathbf{P} \\
\text { Val } \\
\text { ue }\end{array}$} \\
\hline & \multicolumn{2}{|c|}{$\begin{array}{c}\text { Kuran } \\
\text { g }\end{array}$} & \multicolumn{2}{|c|}{ Patuh } & & & \\
\hline & $\mathbf{n}$ & $\%$ & $\mathbf{n}$ & $\%$ & $\mathbf{N}$ & $\%$ & \\
\hline Tida & 1 & 26 , & 5 & 73,9 & 69 & 10 & \\
\hline $\mathrm{k}$ & 8 & 1 & 1 & 41,9 & 31 & 0 & 0,00 \\
\hline Bkrj & 1 & 58, & 1 & & & 10 & 4 \\
\hline $\mathrm{a}$ & 8 & 1 & 3 & & & 0 & \\
\hline Tota & 3 & 36 , & 6 & 64,0 & 10 & 10 & \\
\hline 1 & 6 & 0 & 4 & & 0 & 0 & \\
\hline
\end{tabular}

Tabel 1.4 menunjukkan bahwa responden yang tidak bekerja sebagian besar patuh dalam program diet yaitu sebanyak 51 orang $(73,9 \%)$. Hasil uji statistik dengan uji chi square diperoleh $\mathrm{p}$ value $0,004<0,05$ terdapat hubungan yang signifikan antara pendidikan dengan kepatuhan diet. Nilai Odd Ratio (OR) 3,923 dengan Confidence Interval (CI) 95\% 1,606-9,583 artinya responden yang tidak bekerja memberikan peluang 3,923 kali patuh dengan program diet dibandingkan dengan responden yang bekerja. penelitian Macgilchrist (2010) bahwa ada hubungan antara status pekerjaan dengan kepatuhan pengelolaan diet pasien DM. Penderita DM yang memiliki pendapatan yang rendah lebih tidak patuh dalam mengelola diet dibandingkan dengan orang yang memiliki pendapatan tinggi. Hal ini dikarenakan orang yang mempunyai pendapatan rendah lebih sedikit berpeluang untuk membeli makanan yang sesuai dengan diet diabetes daripada yang berpendapatan tinggi.

Tabel 1.5 Hubungan Pengetahuan dengan Kepatuhan Diet

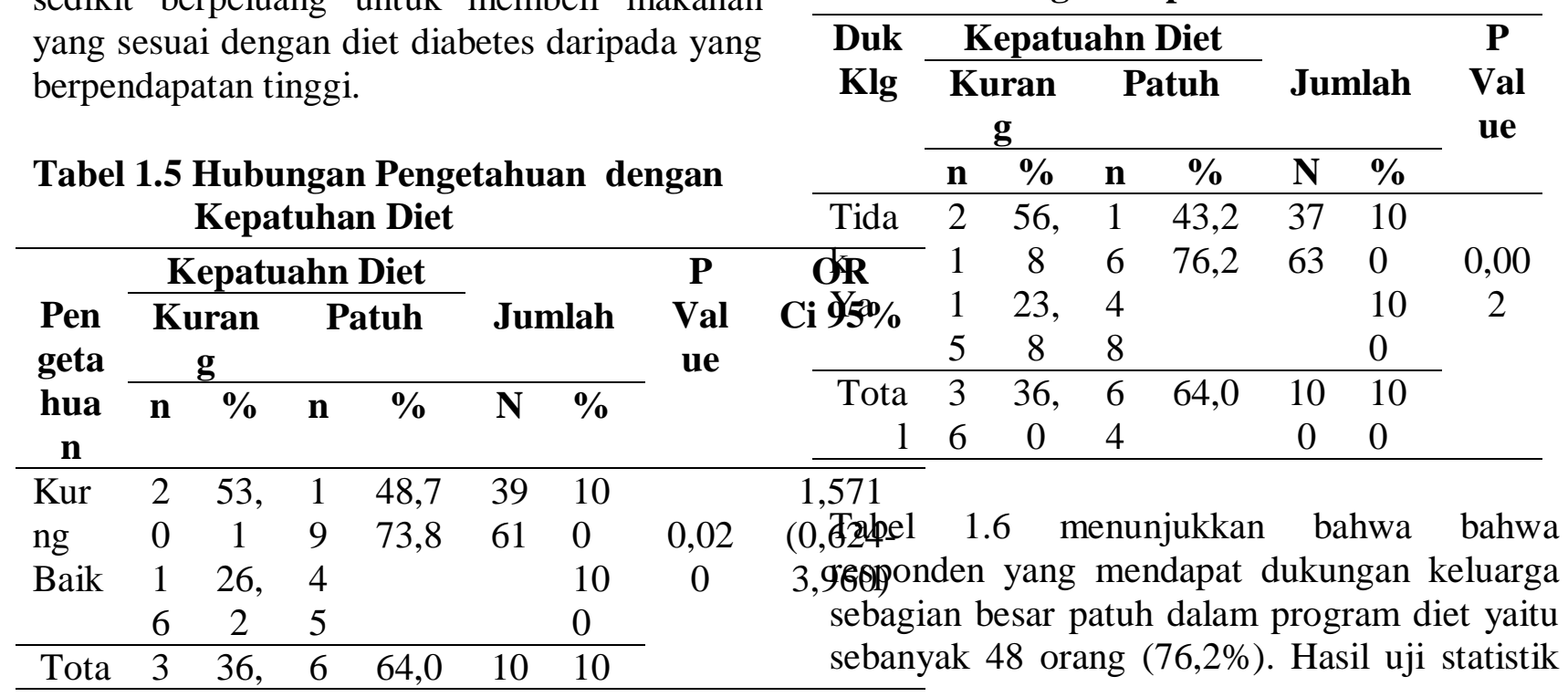

Tabel 1.5 menunjukkan bahwa responden yang memiliki pengatahuan baik sebagian besar patuh dalam program diet yaitu sebanyak 45 orang $(73,8 \%)$. Hasil uji statistik dengan uji chi square diperoleh $\mathrm{p}$ value $0,020<0,05$ terdapat hubungan yang signifikan antara pendidikan dengan kepatuhan diet. Nilai Odd Ratio (OR) 2,961 dengan Confidence Interval (CI) 95\% 1,267-6,915 artinya responden yang memiliki pengetahuan baik memberikan peluang 2,961 kali patuh dengan program diet dibandingkan dengan responden yang memiliki pengetahun kurang baik. Penelitian ini sejalan dengan penelitian yang dilakukan oleh Tania (2016) pada pasien rawat jalan DM tipe 2 di RSUP Fatmawati, menyatakan bahwa responden yang mempunyai tingkat pengetahuan baik 12,5 kali lebih patuh dalam diet dibandingkan dengan responden yang berpengetahuan kurang. Hasil penelitian juga menunjukkan bahwa tingkat pengetahuan menjadi faktor risiko terhadap kepatuhan diet yang dijalankan pasien DM tipe 2. Tingkat pengetahuan yang kurang dapat menghambat perilaku kepatuhan dalam kesehatan karena penderita akan sulit untuk mengikuti anjuran dari petugas kesehatan, sehingga penderita diabetes mellitus yang mempunyai tingkat pengetahuan baik lebih paham dan mengerti mengenai anjuran dalam mengelola diet.

\section{Tabel 1.6 Hubungan Dukungan Keluarga} dengan Kepatuhan Diet 
dengan uji chi square diperoleh p value $0,002<$ 0,05 terdapat hubungan yang signifikan antara pendidikan dengan kepatuhan diet. Nilai Odd Ratio (OR) 4,200 dengan Confidence Interval (CI) 95\% 1,757-10,038 artinya responden yang mendapat dukungan keluarga memberikan peluang 4,200 kali patuh dengan program diet dibandingkan dengan responden yang tidak mendapat dukungan keluarga. Penelitian Senuk (2013) menggambarkan hasil bahwa dukungan keluarga mempunyai hubungan dengan kepatuhan dalam menjalani diet DM. Hasil tersebut juga didukung oleh penelitian dari Susanti (2013) yang menyatakan bahwa dukungan keluarga memiliki hubungan terhadap kepatuhan diet pasien.

Tabel 1.7 Hubungan Dukungan Tenaga Kesehatan dengan Kepatuhan

Diet

\begin{tabular}{|c|c|c|c|c|c|c|c|}
\hline \multirow{3}{*}{$\begin{array}{c}\text { Duk } \\
\text { Nak } \\
\text { S }\end{array}$} & \multicolumn{4}{|c|}{ Kepatuahn Diet } & \multirow{2}{*}{\multicolumn{2}{|c|}{ Jumlah }} & \multirow{3}{*}{$\begin{array}{c}\mathbf{P} \\
\text { Val } \\
\text { ue }\end{array}$} \\
\hline & \multicolumn{2}{|c|}{$\begin{array}{c}\text { Kuran } \\
\text { g }\end{array}$} & \multicolumn{2}{|c|}{ Patuh } & & & \\
\hline & $\mathbf{n}$ & $\%$ & $\mathbf{n}$ & $\%$ & $\mathbf{N}$ & $\%$ & \\
\hline Tida & 1 & 34 , & 3 & 66,0 & 50 & 10 & \\
\hline $\mathrm{k}$ & 7 & 0 & 3 & 62,0 & 50 & 0 & 0,83 \\
\hline \multirow[t]{2}{*}{ Ya } & 1 & 38 , & 3 & & & 10 & 5 \\
\hline & 9 & 0 & 1 & & & 0 & \\
\hline \multirow{2}{*}{$\begin{array}{r}\text { Tota } \\
1\end{array}$} & 3 & 36 , & 6 & 64,0 & 10 & 10 & \\
\hline & 6 & 0 & 4 & & 0 & 0 & \\
\hline
\end{tabular}

Tabel 1.6 menunjukkan bahwa responden yang kurang mendapat dukungan tenaga kesehatan sebagian besar patuh dalam program diet yaitu sebanyak 33 orang $(66,0 \%)$. Hasil uji statistik dengan uji chi square diperoleh $p$ value $0,835>$ 0,05 tidak terdapat hubungan yang signifikan antara pendidikan dengan kepatuhan diet.

\section{Analisis Multivariat}

Setelah dilakukan analisis bivairat, selanjutnya dilakukan analisis multivariat yang bertujuan untuk mengetahui hubungan yang paling dominan antara variabel independen dengan dependen

Tabel 1.7 Pemodelan Awal

\begin{tabular}{lcccc}
\hline \multicolumn{1}{c}{ Variabel } & $\begin{array}{c}\text { P } \\
\text { Value }\end{array}$ & OR & \multicolumn{2}{c}{$\mathbf{9 5 \%}$ CI For } \\
& 0,182 & 0,43 & 0,13 & 1,470 \\
\hline Umur & 0,776 & 9 & 1 & 3,400 \\
Jenis & 0,801 & 1,16 & 0,40 & 3,925 \\
Kelamin & & & &
\end{tabular}

\begin{tabular}{lcccc}
\hline Pendidikan & 0,001 & 8 & 1 & 0,416 \\
Pekerjaan & 0,006 & 0,81 & 0,17 & 0,645 \\
Pengetahuan & 0,000 & 7 & 0 & 0,370 \\
Dukungan & 0,538 & 0,11 & 003 & 2,148 \\
Keluarga & & 5 & 2 & \\
Dukungan & & 0,22 & 0,07 & \\
Tenaga & & 4 & 7 & \\
Kesehatan & & 0,11 & 0,03 & \\
& & 5 & 6 & \\
& & 0,70 & 0,23 & \\
& & 5 & 1 & \\
\hline
\end{tabular}

Tabel 1.8 Pemodelan Akhir

\begin{tabular}{lcccc}
\hline \multicolumn{1}{c}{ Variabel } & $\begin{array}{c}\text { P } \\
\text { Val }\end{array}$ & OR & \multicolumn{2}{c}{$\begin{array}{c}\text { 95\% CI For } \\
\exp (\boldsymbol{\beta})\end{array}$} \\
\hline Pekerjaan & 0,00 & 7,25 & 2,30 & 22,86 \\
Pengetahuan & 1 & 5 & 2 & 9 \\
Dukungan & 0,00 & 0,21 & 0,07 & 0,618 \\
Keluarga & 4 & 6 & 5 & 0,379 \\
& 0,00 & 0,12 & 0,04 & \\
& 0 & 4 & 0 & \\
\hline
\end{tabular}

Tabel 1.8 menunjukkan pemodelan akhir analisis multivariat bahwa faktor dominan yang mempengaruhi kepatuhan diet DM adalah faktor pekerjaan, pengetahuan, dan dukungan keluarga. Faktor pekerjaan memberikan peluang 7,255 kali mempengaruhi kepatuhan diet diabetes melitus (C.I. 2,302-22,869), dan faktor pengetahuan, dan dukungan keluarga memberikan peluang 0,124-0,467 kali mempengaruhi kepatuhan diet diabetes. Sedangkan variabel yang menjadi counfounding adalah variabel dukungan tenaga kesehatan.

\section{KESIMPULAN}

Berdasarkan uraian dari hasil penelitian dan pembahasan, maka dengan ini penulis mengambil kesimpulan sebagai berikut:

1. Responden yang patuh dalam program diet sebanyak 64 orang (64\%),

2. Variabel yang memiliki hubungan sebab akibat dengan kepatuhan diet diabetes melitus adalah umur, pekerjaan, pengetahuan, dan dukungan keluraga.

a. Faktor pekerjaan memberikan peluang 7,255 kali mempengaruhi kepatuhan diet diabetes melitus (C.I. 2,302 22,869). 
b. Faktor umur, pengetahuan, dan dukungan keluarga memberikan peluang 0,124-0,467 kali mempengaruhi kepatuhan diet diabetes.

3. Variabel yang tidak memiliki hubungan sebab akibat dengan kepatuhan diet diabetes melitus adalah jenis kelamin, pendidikan, dan dukungan teanaga kesehatan.

\section{SARAN}

Disarankan bagi pihak Puskesmas dapat memanfaatkan data hasil penelitian ini untuk peningkatan kompetenis petugas dalam mendukung kepatuhan program diet pada penderita diabetes melitus.

\section{DAFTAR PUSTAKA}

Akmal, H.F. and Puruhita, N., (2012). Perbedaan Asupan Energi, Protein, Aktivitas Fisik dan Status Gizi antara Lansia yang Mengikuti dan Tidak Mengikuti Senam Bugar Lansia: Studi Kasus di Instalasi Geriatri Paviliun Lanjut Usia Prof. Dr. Boedhi Darmojo RSUP Dr. Kariadi Semarang. Jurnal Media Medika Muda

American Diabetes Association (ADA), 2011 , Diagnosis Dan Klasifikasi. Diabetes Mellitus, Perawatan Diabetes, 34, 62-9. Adibe, MO, Ukwe, CV, Aguwa.

Arikunto, S.(2010). Prosedur penelitian suatu pendekatan praktik, Jakarta: Rhineka Cipta

\section{American Diabetes Association.(2010).}

Standart of medical care in diabetes Diabetes care.

Badan Pengawas Obat dan Makanan. (2006).Kepatuhan pasien faktor penting dalam keberhasilan terapi. Vol.7 no 5.

Budiyanto. (2002). Gizi dan kesehatan. Malang: Bayu Media dan UMM Press.

Darmono. (2007). Pola hidup sehat penderita diabetes melitus. Semarang: Badan
Penerbit Universitas Diponegoro. diabetes melitus terpadu. Jakarta: Balai Penerbit FKUI

Dorland, N (2002). Kamus Kedokteran Dorland. Edisi 29,. Jakarta:EGC

Green L.W, Kreuter M.(200). Health promotion planning: an educational and environmental approach. Mayfield publishing company, 2nd edition; 2000.

Gustaviani R.(2007). Sindrome Metabolik. Ilmu Penyakit Dalam. Jakarta : Pusat Penerbitan Ilmu Penyakit Dalam FKUI

Hadi Z.(2004). Pelayanan dasar penanganan diabetes melitus di Puskesmas.

Hartono A.(2005). Terapi gizi dan diet rumah sakit. Yogyakarta: EGC

Heryati, G.S., 2014. Faktor-Faktor yang Berhubungan dengan Kepatuhan Diet Diabetes Mellitus pada Pasien DM. Jurnal Keperawatan, 1(3): 97-107.

Ignatavicius, D. dan Workman, L. (2013) Perawatan Bedah Medis: Perawatan Kolaboratif Berpusat pada Pasien. Edisi 7, Elsevier Inc., St. Louis.

Liu, L. L., \& Park, D. C. (2004). Aging and Medial Adherence: The Use of Automatic Processes to Achieve Effortful Things. Psychology and Aging, 19, 318-325

Mahan LK, Stump SE. Krause's (2004). Food nutrition and diet therapy, Pensylvania: WB Saunders

Mellin A, Sztainer DN, Patterson J, Sockalosky J,. (2004). Unhealthy weight management behavior among adolescent girls with type 1 diabetes mellitus: the role of familial eating patterns and weight-related concerns.

Moleong LJ (2010). Metodologi penelitian kualitatif. Bandung: Remaja Rosdakarya 
Notoatmojo S. (2010). Ilmu perilaku kesehatan. Jakarta: PT. Rineka Cipta

(2010). Metodologi penelitian kesehatan. Jakarta : Rineka Cipta

Nugroho, Y.W. and Handono, N.P., (2017). Hubungan Tingkat Kepatuhan Diet terhadap Kadar Glukosa Darah pada Penderita Diabetes Mellitus di Kelurahan Bulusulur. Jurnal KEPERAWATAN GSH, 6(1).

Pamorita A. (2005). Efek pemberian bekatul terhadap kadar gula darah. Jakarta: Balai Penerbit

Perkumpulan Endrokrinologi Indonesia (2011). Konsensus pengelolaan dan pencegahan diabetes melitus tipe 2 di Indonesia. Jakarta

Saryono, Anggaraeni MD (2010). Metodologi penelitian kualitatif dalam bidang kesehatan. Yogyakarta: Nuha Medika

Senuk, A., Supit, W., dan Onibala, F. (2013). Hubungan Pengetahuan dan Dukungan Keluarga dengan Kepatuhan Menjalani Diet Diabetes Mellitus di Poliklinik RSUD Kota Tidore Kepulauan Provinsi Maluku Utara. ejournal Keperawatan, 1 (1): 1-7

Setiadi. (2013). Konsep dan Praktik Penulisan Riset Keperawatan Edisi 2. Yogyakarta : Graha Ilmu

Setiawati SH (2004). Penatalaksanaan diabetes melitus terpadu, Jakarta: Balai Penerbit FKUI;

Soe Smeltzer, S., \& Bare, B. (2013). Buku ajar Keperawatan Medikal-Bedah Brunner dan Suddart Volume 1 Edisi 8. Jakarta: EGC.

Subekti. (2005). Neuropati diabetik. Ilmu penyakit dalam. Jakarta EGC.

Sugyono. (2009). Metodologi penelitian. Yogyakarta : Graha Ilmu
Suyono S. Patofisiologi diabetes melitus, Jakarta: EGC

Tania, M., (2016). Hubungan Pengetahuan Remaja dengan Perilaku Konsumsi Minuman Ringan di SMKN 2 Baleendah Bandung. Keperawatan, 4(1).

Tarwoto. (2012). Keperawatan Medikal Bedah Gangguan Sistem Endokrin. Jakarta: Trans Info Medikal.

Trisnawati, S. K.., \& Setyorono, S. (2013). Faktor Risiko Kejadian Diabetes Mellitus Tipe 2 di Puskesmas Kecamatan Cengkareng Jakarta Barat Tahun 2012. Jurnal Ilmiah Kesehatan, 5 (1): 1-11

B Tjokroprawiro, (2010).Buku Ajar Ilmu Penyakit Dalam. Surabaya : Airlangga University Press, 2007; 29.

Trisnawati, S. K. (2013). Faktor Risiko Kejadian Diabetes Melitus Tipe II di Puskesmas Kecamatan Cengkareng Jakarta Barat Tahun 2012. Jurnal Ilmiah Kesehatan, 5, 6-11.

Waspadji S. (2004). Diabetes melitus: mekanisme dasar dan pengelolaannya yang rasional. Jakarta: Balai Penerbit FKUI

Waspadji S, Sukardji K, Octarina M. (2007). Pedoman diet diabetes melitus. Jakarta: FKUI

World Health Organization. Use of Glycated Haemoglobin (HbAlc) in the Diagnosis of Diabetes Mellitus tipe 2 Abbreviated Report of a WHO Consultation. World Health Organization. 2011. 